\title{
Shaking weight loss away - Can vibration exercise reduce body fat?
}

\author{
DARRYL COCHRANE
}

Sport Coaching and Management Program, Department of Management, Massey University, Palmerston North, New Zealand

\begin{abstract}
Cochrane D. Shaking weight loss away - Can vibration exercise reduce body fat? J. Hum. Sport Exerc. Vol. 6 , No. 1, pp. 33-39, 2011. An exercise modality that requires little time and physical exertion whilst providing the benefits of increased force, power, balance, flexibility, and weight loss would appeal to most people that may be at risk from an imbalanced lifestyle. One such exercise modality that has received a lot of attention has been vibration exercise $(\mathrm{VbX})$, which evokes muscular work and elevates metabolic rate could be a potential method for weight reduction. Popular press has purported that $\mathrm{VbX}$ is quick, convenient, and 10 minutes of $\mathrm{VbX}$ is equivalent to one hour of traditional exercise, where it has been marketed as the new weight-loss and body toning workout. However, research studies have shown that muscle activation is elicited but the energy demand in response to $\mathrm{VbX}$ is quite low. Exhaustive $\mathrm{VbX}$ has been reported to produce a metabolic demand of $23 \mathrm{ml} / \mathrm{kg} / \mathrm{min}$ compared to $44 \mathrm{ml} / \mathrm{kg} / \mathrm{min}$ from an exhaustive cycle test. Different vibration frequencies have been tested with varying amplitudes and loads, but only small increases in metabolic rate have been reported. Based on these findings it has been indirectly calculated that a $\mathrm{VbX}$ session of $26 \mathrm{~Hz}$ for 3 continuous minutes would only incur a loss of $\sim 10.7 \mathrm{~g}$ fat/hr. Following a 24-week programme of $\mathrm{VbX}$, no observed differences were found in body composition and following 12 months of $\mathrm{VbX}$ the time to reach peak $\mathrm{O}_{2}$ was significantly higher in conventional exercise compared to $\mathrm{VbX}$. However, one study has reported that percentage body fat decreased by $3.2 \%$ after eight months after $\mathrm{VbX}$ in comparison to resistance and control groups that performed no aerobic conditioning. The evidence to date, suggests that $\mathrm{VbX}$ can increase whole and local oxygen uptake; however, with additional load, high vibration frequency and/or amplitude it cannot match the demands of conventional aerobic exercise. Therefore, caution is required when $\mathrm{VbX}$ programmes are solely used for the purpose of reducing body fat without considering dietary and aerobic conditioning guidelines. Key words: WEIGHT LOSS, MUSCLE METABOLISM, OXYGEN CONSUMPTION, BODY COMPOSITION
\end{abstract}

Corresponding author. Department of Management. Massey University. Private Bag 11 222. Palmerston North. New Zealand.

E-mail: D.Cochrane@massey.ac.nz

Submitted for publication July 2010.

Accepted for publication November 2010.

JOURNAL OF HUMAN SPORT \& EXERCISE ISSN 1988-5202

(c) Faculty of Education. University of Alicante

doi:10.4100/jhse.2011.61.04 


\section{INTRODUCTION}

In a society where physical activity is on the decline and obesity is on the rise there is a need to find new methods and modalities to promote healthy and beneficial exercise. An exercise modality that requires little time and physical exertion but provides benefits to increase muscle force, power, balance, flexibility, and weight loss would appeal to most people that lead busy lifestyles or are at risk from a lifestyle imbalance. One such exercise modality that has received a lot of attention has been vibration exercise $(\mathrm{VbX})$, which is purported to enhance, sports performance (Cochrane \& Stannard, 2005; Issurin, Liebermann, \& Tenenbaum, 1994; Sands et al., 2008), exercise compliance (Hannan et al., 2004), health (Bautmans, Van Hees, Lemper, \& Mets, 2005; Bruyere et al., 2005), and exercise-associated rehabilitation (Moezy, Olyaei, Hadian, Razi, \& Faghihzadeh, 2008; Rittweger, Just, Kautzsch, Reeg, \& Felsenberg, 2002; Salvarani et al., 2003). VbX initiates a rapidly and repeating eccentric-concentric action that evokes muscular work and elevates metabolic rate (Rittweger, Beller, \& Felsenberg, 2000). This is achieved by standing on a commercially manufactured machine with an oscillating platform that produces side-alternating vertical sinusoidal asynchronous vibration (SV) or moves predominately in the vertical direction to produce vertical synchronous vibration (VV). Using low vibration frequency $(5-45 \mathrm{~Hz})$ it has been reported to increase muscle activity (Abercromby et al., 2007; Bosco, Cardinale, \& Tsarpela, 1999; Cardinale \& Lim, 2003; Roelants, Verschueren, Delecluse, Levin, \& Stijnen, 2006) where the excitatory response of the muscle spindle is speculated to play a role in enhancing muscle activation, involving the spinal reflex mechanism (Cardinale \& Bosco, 2003; Rittweger, Mutschelknauss, \& Felsenberg, 2003), which may raise energy demand and be beneficial for weight reduction.

$\mathrm{VbX}$ has gained popularity with a plethora of vibration machines being used in fitness centres, studios, and gyms, but it has been subjected to hype and sensationalism. There have been reports in the lay literature that $\mathrm{VbX}$ reduces the workout time but provides the full benefits of a normal workout, which can reduce body fat. In some instances it has been reported that a 10 minute $\mathrm{VbX}$ session is equivalent to one hour of traditional exercise. Therefore, the aim of this opinion is to provide the readers with the scientific evidence on the use of $\mathrm{VbX}$ to reduce body fat.

\section{OXYGEN COST OF VbX}

From electromyography- $\mathrm{VbX}$ studies there is strong evidence to suggest that muscle activation is elicited (Bosco et al., 1999; Cardinale \& Lim, 2003; Issurin \& Tenenbaum, 1999; Roelants, Delecluse, Goris, \& Verschueren, 2004; Ronnestad, 2004); however, the energy demand in response to VbX is quite low. Rittweger et al. (2000) compared the exhaustive effects of vibration with additional load ( $40 \%$ of body mass) to that of exhaustive cycling, and found that vibration (frequency $[f]=26 \mathrm{~Hz}$, Amplitude $[A]=10.5 \mathrm{~mm}$, SV) could only elicit a metabolic demand of $23 \mathrm{ml} / \mathrm{kg} / \mathrm{min}$ compared to $44 \mathrm{ml} / \mathrm{kg} / \mathrm{min}$ of the cycle test. In a follow up study, Rittweger et al. (2001) found that $\mathrm{VbX}(f=26 \mathrm{~Hz}, A=6 \mathrm{~mm}$, SV) elicited $10.2 \mathrm{ml} / \mathrm{kg} / \mathrm{min}$ compared to no vibration of $4.8 \mathrm{ml} / \mathrm{kg} / \mathrm{min}$, while dynamic squatting at a tempo of $3 \mathrm{~s}$ up and $3 \mathrm{~s}$ down (to $90^{\circ}$ knee flexion) for three minutes recorded $14 \mathrm{ml} / \mathrm{kg} / \mathrm{min}$ with vibration and $10.7 \mathrm{ml} / \mathrm{kg} / \mathrm{min}$ without vibration. The authors propose that the increase in oxygen uptake was indirectly related to muscle activity and vibration at $26 \mathrm{~Hz}(A=6 \mathrm{~mm})$ was equivalent to moderate walking at $4.5 \mathrm{~km} / \mathrm{hr}(1.25 \mathrm{~m} / \mathrm{s})$.

In a further study Rittweger et al. (2002) quantified the effect of metabolic demand by examining a range of vibration frequencies $(f=18,26,34 \mathrm{~Hz})$ and amplitudes $(A=2.5,5,7.5 \mathrm{~mm})$. They reported that oxygen uptake increased proportionally to an increase in vibration frequency, with external load showing a similar trend. However, oxygen uptake increased exponentially, especially at higher amplitudes of $5 \mathrm{~mm}$ and 
$7.5 \mathrm{~mm}$. The researchers concluded that the increase in oxygen demand may be parametrically controlled by frequency, amplitude, and external load when applying vibration. The aforementioned studies (Rittweger et al., 2000; Rittweger et al., 2002; Rittweger et al., 2001) suggest that vibration may cause a small increase in metabolic rate that results from muscular work and reflects a reflex response, for which TVR may be responsible.

Using indirect calorimetry procedures, Da Silva et al. (2007) reported that $\mathrm{VbX}(f=30 \mathrm{~Hz}, A=4 \mathrm{~mm}, \mathrm{~V})$ with 10RM half-squats produced a significantly higher energy expenditure $(18.8 \mathrm{~kJ} / \mathrm{min})$ compared to without vibration (15.9 kJ/min). This is equivalent to Rittweger's et al. (2001) finding of $\sim 19.3 \mathrm{~kJ} / \mathrm{min}$ of squatting with vibration and confirms that energy expenditure is enhanced when vibration is combined with resistance exercise. Moreover, Garatachea et al. (2007) found that a fast cadence 2s (1s up, 1s down) of dynamic squatting with vibration ( $f=30 \mathrm{~Hz}, A=4 \mathrm{~mm}, \mathrm{~V}$ ) produced a greater oxygen cost and higher total energy expenditure compared to slower squatting cadences of $4 \mathrm{~s}$ (2s up, 2s down) and $6 \mathrm{~s}$ (3s up, 3s down). However, fat oxidation was higher and carbohydrate oxidation was lower in the slower cadence of $6 \mathrm{~s}$, suggesting that slower squatting may be more effective for fat burning, but the total energy expenditure was lower in the faster squat, which was calculated from $\mathrm{V}_{2}$ and respiratory exchange ratio.

An estimation of the energy cost of vibration $(f=26 \mathrm{~Hz}, A=6 \mathrm{~mm})$ can be indirectly calculated. Based on Rittweger et al. (2001) findings that three minutes of $\mathrm{VbX}(f=26 \mathrm{~Hz}, A=6 \mathrm{~mm}, \mathrm{SV})$ for a $70 \mathrm{~kg}$ person increases oxygen uptake by $4.5 \mathrm{ml} / \mathrm{kg} / \mathrm{min}$ would equate to an expenditure of $18.9 \mathrm{~L}$ of $\mathrm{O}_{2} / \mathrm{hr}$. Assuming an energy equivalent of $20.9 \mathrm{~kJ} / \mathrm{L}$ of $\mathrm{O}_{2}$ and a caloric equivalent of $37 \mathrm{~kJ} / \mathrm{g}$ of body fat, this would accrue a loss of $\sim 10.7 \mathrm{~g}$ fat/hr ([18.9x20.9]/37). Therefore, it is unlikely that $\mathrm{VbX}$ can be exclusively used as a form of aerobic exercise to reduce body fat. This has been be supported by Roelants et al. (2004), who observed no changes in the body composition of body weight, percentage body fat or skinfold thickness in young untrained females following 24 weeks (3X/week) of $\mathrm{VbX}$ in comparison to combined cardiovascular/resistance training or control conditions. Although these young female participants were classified as untrained, no specific data was given on their baseline fitness levels; however, the vibration group were non-significantly heavier $(3.8 \mathrm{~kg})$ and had a higher percentage body fat $(2.5 \%)$ compared to cardiovascular/resistance group. A further limitation was the volume and training intensity between vibration and cardiovascular/resistance training groups were not identically matched. However, this is difficult to achieve, because there are currently no prescription guidelines to increase the vibration parameters in a progressive and systematic fashion.

Given the limitations of Roelants et al. (2004) study, it still confirms that $\mathrm{VbX}$ cannot reduce body fat, which requires a combined strategy of conventional aerobic exercise with dietary changes (Hammer, Barrier, Roundy, Bradford, \& Fisher, 1989). However, Roelants et al. (2004) did report an increase in muscle strength and fat free mass (FFM) from the vibration group; therefore, changes in body composition may have gone undetected by the increases in lean muscle tissue, but a reduction in FFM should have also coexisted however, FFM actually increased. Conversely, Fjeldstad et al. (2009) reported that percentage body fat decreased by $3.2 \%$ in sedentary postmenopausal women who performed $\mathrm{VbX}$ ( $f=30$ \& $40 \mathrm{~Hz}$, $A=3 \mathrm{~mm}, \mathrm{VV}$ ) for eight months (3x/week) in comparison to resistance and control groups. However, increases in lean tissue mass for the total body, arm and trunk were similar between vibration and resistance training groups after eight months. The difference between the findings of Fjeldstad et al. (2009) and Roelants et al. (2004) is that participants were younger and more active compared to Fjeldstad's et al. (2009) postmenopausal women. Moreover, the resistance training group of Fjeldstad et al. (2009) performed resistance exercises only; in comparison Roelants et al. (Roelants et al., 2004) performed both resistance and aerobic exercises which would have increased the metabolic rate. Finally, the method of 
measuring body composition differed between the two studies. Fjeldstad et al. (2009) used DEXA (dual energy X-ray absorptiometry) and Roelants et al. (2004) used under-water weighing, and skinfolds.

Recently, a 12 month study was conducted on older men and women (60-80yr) to investigate the effect of intermittent vibration ( $f=35 \& 40 \mathrm{~Hz}, A=2.5 \& 5 \mathrm{~mm}, \mathrm{~V})$ and conventional exercise (aerobic, resistance, balance, and flexibility) on cardio-respiratory fitness (Bogaerts et al., 2009). The researchers observed that post-training $\mathrm{VO}_{2}$ peak was significantly higher in both $\mathrm{VbX}(18 \%)$ and conventional exercise groups $(21 \%)$ compared to control $(8 \%)$. However, the time to reach peak $\mathrm{V}_{2}$ was significantly higher $(14 \%)$ in conventional exercise compared to $\mathrm{VbX}(9 \%)$ and control $(6 \%)$. Caution is required when interpreting the results as the vibration and conventional groups were not matched for intensity, metabolism, or load. Further, no measurement of the metabolic cost was taken during the vibration or conventional exercise sessions, and the study lacked a placebo condition.

\section{MUSCLE METABOLISM AND VbX}

A few studies have examined local muscle metabolism using near-infrared spectroscopy (NIRS) technology with varying results. Yamada et al. (2005) found that fast dynamic squatting for three minutes with vibration ( $f=15 \mathrm{~Hz}, A=2.5 \mathrm{~mm}, \mathrm{SV}$ ) increased muscle oxygenation of the vastus lateralis compared to squatting with no vibration, which the authors attributed to an increase in oxygen uptake. Further confirmation that vibration increases oxygen consumption through muscle activation has also been made by Mileva et al. (2006). They observed that the rate of vastus lateralis deoxygenation (as estimated from the slope of $\mathrm{HHb}$ ) was significantly faster $(32 \%)$ after $35 \% 1 \mathrm{RM}$ knee extension exercise with vibration, compared to nonvibration. On the contrary, Cardinale et al. (2007) found no significant differences between muscle oxygenation levels of vastus lateralis and gluteus maximus performed at $30,40,50 \mathrm{~Hz}(A=4 \mathrm{~mm}, \mathrm{VV})$. The difference between these findings may be explained by the different protocols of the exposure time, vibration platform type (VV vs. SV), vibration frequency, and body positions.

Recently, there has been some support for the idea that muscle perfusion may play an important role in $\mathrm{VbX}$. Using ${ }^{31} \mathrm{P}$ magnetic resonance spectroscopy ( $\left.{ }^{31} \mathrm{P}-\mathrm{MRS}\right)$, Zange et al. (2009) reported an increase in ATP consumption from a custom built vibration pedal $(f=20 \mathrm{~Hz}, A=2 \mathrm{~mm})$ but it was not significantly different to no vibration. However, when arterial occlusion was applied to the ipsilateral thigh, ATP consumption increased by $60 \%, \mathrm{PCr}$ increased by $35 \%$ and $\mathrm{pH}$ by 0.16 units compared to no vibration. This confirms the findings of Rittweger et al. (2001) that VbX elevates metabolism, but it cannot elevate energy turnover by large amounts. But some companies advocate that a 10 minute workout on $\mathrm{VbX}$ platform is equivalent to one hour of traditional exercise, to a less extent this may be true, because a VbX session of 5 minutes at a vibration frequency of $26 \mathrm{~Hz}$ is capable of producing 7,800 muscle contractions which is not possible in any conventional exercise regime. Nevertheless, some peer-reviewed published research has been misinterpreted by the lay press to increase machine sales. For instance, one company has been quoted that "a 12-week study found that strength increases from an average of 10 minutes of vibration training were similar to those seen in an hour of regular resistance training". However, on closer examination of this study found that the participants were progressively exposed to $\mathrm{VbX}$ from a total of 3 min to 20 min over the 12 week period. Notably, the resistance training group performed a 20 min warm-up followed by 11 min of resistance training (based on $20 \mathrm{RM}$ at a tempo of $3 \mathrm{~s}$ up and $3 \mathrm{sec}$ down, 2 sets of 2 exercises separate by 1 min recovery). Additionally, it has been reported that the metabolic cost of $\mathrm{VbX}$ is much smaller than conventional aerobic exercise, which makes it difficult to reduce body fat, even a higher frequency, amplitude, and additional loading will not drastically increase the ability to elevate energy turnover by large amounts (Rittweger et al., 2000; Rittweger et al., 2001). Lastly, it has been reported in the lay literature that 
people who use the VbX platforms feel toned after a session, indicating that fat burning has taken place. This is unlikely to be true, it has been proposed that an increase in blood flow and intramuscular pressure of the lower extremities is responsible for this but further research is required to confirm this.

\section{CONCLUSION}

The evidence firmly suggests that $\mathrm{VbX}$ can increase whole and local oxygen uptake; however, with additional load, high vibration frequency and/or amplitude it cannot match the demands of conventional aerobic exercise. Therefore, caution is required when a $\mathrm{VbX}$ programme is solely used for the purpose of reducing body fat without considering dietary and aerobic conditioning guidelines. To date, only one study has reported that $\mathrm{VbX}$ is able to burn extra calories but it cannot reduce overall body fat(Fjelstad et al., 2009). Akin to Rittweger's et al. $(2000,2001)$ studies have conclusively reported that vibration is not a suitable option to reduce body weight, as the metabolic cost of a 'standard' vibration session is equivalent to burning only $10 \mathrm{~g} / \mathrm{hr}$. Finally, it is equivocal whether the increase in energy turnover can be accounted for by an increase in muscle activation caused by neural potentiation, which has been based on spinal reflexes. However, to date, no direct measures of muscle have been made to verify that $\mathrm{VbX}$ acts solely through a reflex potentiation causing a change in muscle length that increases oxygen uptake. It has been suggested by Cardinale and Bosco (2003) that vibration causes small and rapid changes in muscle length by eliciting reflex muscle activity in an attempt to damp the mechanical vibration, where various researchers have speculated that the muscle activation is similar to that of TVR (Bosco et al., 1999; Bosco et al., 1998; Cardinale \& Bosco, 2003; Cardinale \& Lim, 2003; Cardinale \& Rittweger, 2006; Rittweger et al., 2000).

\section{REFERENCES}

1. ABERCROMBY AFJ, AMONETTE WE, LAYNE CS, MCFARLIN BK, HINMAN MR, PALOSKI WH. Variation in neuromuscular responses during acute whole-body vibration exercise. Medicine and Science in Sports and Exercise. 2007; 39(9):1642-1650. [Abstract] [Back to text]

2. BAUTMANS I, VAN HEES E, LEMPER JC, METS T. The feasibility of whole body vibration in institutionalised elderly persons and its influence on muscle performance, balance, and mobility: a randomised controlled trial. BMC Geriatrics. 2005; 5(17):1-8. doi:10.1186/1471-2318-5-17 [Back to text]

3. BOGAERTS AC, DELECLUSE C, CLAESSENS AL, TROOSTERS T, BOONEN S, VERSCHUEREN SMP. Effects of whole body vibration training on cardiorespiratory fitness and muscle strength in older individuals (a 1-year randomised controlled trial). Age Ageing. 2009; 38(4):448-454. doi:10.1093/ageing/afp067 [Back to text]

4. BOSCO C, CARDINALE M, TSARPELA O. Influence of vibration on mechanical power and electromyogram activity in human arm flexor muscles. European journal of applied physiology and occupational physiology. 1999; 79(4):306-311. doi:10.1007/s004210050512 [Back to text]

5. BOSCO C, CARDINALE M, TSARPELA O, COLLI R, TIHANYI J, DUVILLARD SP, ET AL. The influence of whole body vibration on jumping performance. Biology of Sport. 1998; 15(3):157-164. [Full Text] [Back to text]

6. BRUYERE O, WUIDART MA, DI PALMA E, GOURLAY M, ETHGEN O, RICHY F, ET AL. Controlled whole body vibration to decrease fall risk and improve health-related quality of life of nursing home residents. Archives of Physical Medicine and Rehabilitation. 2005; 86(2):303-307. doi:10.1016/j.apmr.2004.05.019 [Back to text]

7. CARDINALE M, BOSCO C. The use of vibration as an exercise intervention. Exercise and Sport Sciences Reviews. 2003; 31(1):3-7. [Full Text] [Back to text] 
8. CARDINALE M, FERRARI M, QUARESIMA V. Gastrocnemius medialis and vastus lateralis oxygenation during whole-body vibration exercise. Medicine and Science in Sports and Exercise. 2007; 39(4):694-700. [Full Text] [Back to text]

9. CARDINALE M, LIM J. Electromyography activity of vastus lateralis muscle during whole-body vibrations of different frequencies. Journal of Strength and Conditioning Research. 2003; 17(3):621-624. [Full Text] [Back to text]

10. CARDINALE M, RITTWEGER J. Vibration exercise makes your muscles and bones stronger: fact or fiction? The Journal of the British Menopause Society. 2006; 12(1):12-18. doi:10.1258/136218006775997261 [Back to text]

11. COCHRANE DJ, STANNARD SR. Acute whole body vibration training increases vertical jump and flexibility performance in elite female field hockey players. British Journal of Sports Medicine. 2005; 39(11):860-865. doi:10.1136/bjsm.2005.019950 [Back to text]

12. DA SILVA ME, FERNANDEZ JM, CASTILLO E, NUNEZ V, VAAMONDE DM, POBLADOR MS, ET AL. Influence of vibration training on energy expenditure in active men. Journal of Strength and Conditioning Research. 2007; 21(2):470-475. [Abstract] [Back to text]

13. FJELSTAD C, PALMER IJ, BEMBEN MG, BEMBEN DA. Whole-body vibration augments resistance training effects on body composition in postmenopausal women. Maturitas. 2009; 63:7983. doi:10.1016/j.maturitas.2009.03.013 [Back to text]

14. GARATACHEA N, JIMENEZ A, BRESCIANI G, MARINO NA, GONZALEZ-GALLEGO J, DE PAZ $\mathrm{JA}$. The effects of movement velocity during squatting on energy expenditure and substrate utilization in whole-body vibration. Journal of Strength and Conditioning Research. 2007; 21(2):594-598. [Abstract] [Back to text]

15. HAMMER RL, BARRIER CA, ROUNDY ES, BRADFORD JM, FISHER AG. Calorie-restricted lowfat diet and exercise in obese women. American Journal of Clinical Nutrition. 1989; 49(1):77-85. [Full Text] [Back to text]

16. HANNAN MT, CHENG DM, GREEN E, SWIFT C, RUBIN CT, KIEL DP. Establishing the compliance in elderly women for use of a low level mechanical stress device in a clinical osteoporosis study. Osteoporosis International. 2004; 15(11):918-926. doi:10.1007/s00198-0041637-y [Back to text]

17. ISSURIN VB, LIEBERMANN DG, TENENBAUM G. Effect of vibratory stimulation training on maximal force and flexibility. Journal of Sports Sciences. 1994; 12(6):561-566. [Abstract] [Back to text]

18. ISSURIN VB, TENENBAUM G. Acute and residual effects of vibratory stimulation on explosive strength in elite and amateur athletes. Journal of Sports Sciences. 1999; 17(3):177-182. [Full Text] [Back to text]

19. MILEVA KN, NALEEM AA, BISWAS SK, MARWOOD S, BOWTELL JL. Acute effects of a vibration-like stimulus during knee extension exercise. Medicine and Science in Sports and Exercise. 2006; 38(7):1317-1328. [Full Text] [Back to text]

20. MOEZY A, OLYAEI G, HADIAN M, RAZI M, FAGHIHZADEH S. A comparative study of whole body vibration training and conventional training on knee proprioception and postural stability after anterior cruciate ligament reconstruction. British Journal of Sports Medicine. 2008; 42(5):373-378. doi:10.1136/bjsm.2007.038554 [Back to text]

21. RITTWEGER J, BELLER G, FELSENBERG D. Acute physiological effects of exhaustive wholebody vibration exercise in man. Clinical Physiology. 2000; 20(2):134-142. [Full Text] [Back to text]

22. RITTWEGER J, EHRIG J, JUST K, MUTSCHELKNAUSS M, KIRSCH KA, FELSENBERG D. Oxygen uptake in whole-body vibration exercise: influence of vibration frequency, amplitude, and 
external load. International Journal of Sports Medicine. 2002; 23(6):428-432. doi:10.1055/s-200233739 [Back to text]

23. RITTWEGER J, JUST K, KAUTZSCH K, REEG P, FELSENBERG D. Treatment of chronic lower back pain with lumbar extension and whole-body vibration exercise - A randomized controlled trial. Spine. 2002; 27(17):1829-1834. [Full Text] [Back to text]

24. RITTWEGER J, MUTSCHELKNAUSS M, FELSENBERG D. Acute changes in neuromuscular excitability after exhaustive whole body vibration exercise as compared to exhaustion by squatting exercise. Clinical Physiology and Functional Imaging. 2003; 23(2):81-86. [Full Text] [Back to text]

25. RITTWEGER J, SCHIESSL H, FELSENBERG D. Oxygen uptake during whole-body vibration exercise: comparison with squatting as a slow voluntary movement. European journal of applied physiology. 2001; 86(2):169-173. [Full Text] [Back to text]

26. ROELANTS M, DELECLUSE C, GORIS M, VERSCHUEREN S. Effects of 24 weeks of whole on body composition body vibration training and muscle strength in untrained females. International Journal of Sports Medicine. 2004; 25(1):1-5. doi:10.1055/s-2003-45238 [Back to text]

27. ROELANTS M, VERSCHUEREN SMP, DELECLUSE C, LEVIN O, STIJNEN V. Whole-bodyvibration-induced increase in leg muscle activity during different squat exercises. Journal of Strength and Conditioning Research. 2006; 20(1):124-129. [Full Text] [Back to text]

28. RONNESTAD BR. Comparing the performance-enhancing effects of squats on a vibration platform with conventional squats in recreationally resistance-trained men. Journal of Strength and Conditioning Research. 2004; 18(4):839-845. [Abstract] [Back to text]

29. SALVARANI A, AGOSTI M, ZANRE A, AMPOLLINI A, MONTAGNA L, FRANCESCHIN IM. Mechanical vibration in the rehabilitation of patients with reconstructed anterior cruciate ligament. Europa Medicophysica. 2003; 39(1):19-25. [Full Text] [Back to text]

30. SANDS WA, MCNEAL JR, STONE MH, KIMMEL WL, HAFF GG, JEMNI M. The effect of vibration on active and passive range of motion in elite female synchronized swimmers. European Journal of Sport Science. 2008; 8(4):217-223. doi:10.1080/17461390802116682 [Back to text]

31. YAMADA E, KUSAKA T, MIYAMOTO K, TANAKA S, MORITA S, TSUJI S, ET AL. Vastus lateralis oxygenation and blood volume measured by near-infrared spectroscopy during whole body vibration. Clinical Physiology and Functional Imaging. 2005; 25(4):203-208. [Full Text] [Back to text]

32. ZANGE J, HALLER T, MULLER K, LIPHARDT A, MESTER J. Energy metabolism in human calf muscle performing isometric plantar flexion superimposed by $20-\mathrm{Hz}$ vibration. European Journal of Applied Physiology. 2009; 105:265-270. doi:10.1007/s00421-008-0898-0 [Back to text] 